\title{
HUBUNGAN STATUS SOSIAL EKONOMI ORANG TUA DAN MOTIVASI BELAJAR SISWA DENGAN PRESTASI BELAJAR PENDIDIKAN JASMANI DI SMA NEGERI 1 NGANJUK TAHUN 2021
}

\author{
Novita Nur Synthiawati'), Erawati Di Eriska ${ }^{2)}$, Ilham Faridh ${ }^{3)}$ \\ ${ }^{1}$ Pendidikan Jasmani, STKIP PGRI Jombang \\ Email: novitanur.synthiawati@gmail.com \\ 2 Pendidikan Jasmani, STKIP PGRI Jombang \\ Email: erawatidwieriska@gmail.com \\ ${ }^{3}$ Pendidikan Jasmani, STKIP PGRI Jombang \\ Email: ilhamfaridh85@gmail.com
}

Artikel Info

Koresponden penulis :

Novita Nur Synthiawati

Novitanur.synthiawati@gmail.com

Diterima 28 Juli 2021

Direview 18 Januari 2022

Disetujui 29 Januari 2022

Dipublikasi 31 Januari 2022

Kata kunci

Kondisi Ekonomi, Motivasi Belajar

Keywords:

Economic Conditions, Learning

Motivation

\begin{abstract}
Abstrak
Tujuan dari penelitian ini adalah menelaah ada tidaknya hubungan antara status Sosial Ekonomi Orang Tua dengan prestasi belajar pendidikan jasmani serta Motivasi Belajar Siswa Dengan Prestasi Belajar Pendidikan Jasmani Di SMA Negeri 1 Nganjuk Tahun 2021 dan ada tidaknya hubungan status sosial ekonomi orang tua dan motivasi berprestasi secara bersama-sama dengan prestasi belajar Pendidikan Jasmani Di SMA Negeri 1 Nganjuk Tahun 2021. Penelitian ini menggunakan Pendekatan Korelasional dengan menggunakan metode survey. Hasil dari penelitian ini yaitu hasil analisis korelasi product moment menunjukkan nilai $r$ hitung sebesar $0,719<$ rtabel $(0,05)(111)(0,165)$ maka dapat disimpulkan ada hubungan yang positif dan berpengaruh antara sosial ekonomi dengan prestasi belajar siswa SMAN 1 Nganjuk dalam mata pelajran penjaskes. Hasil analisis korelasi product moment menunjukkan nilai $\mathrm{r}$ hitung sebesar $1>$ rtabel $(0,05)(99)(0,165)$ menunjukkan ada hubungan yang positif. Maka, dapat disimpulkan ada hubungan antara motivasi dengan hasil belajar siswa SMAN 1 Nganjuk dalam mata pelajran penjaskes. Hubungan yang searah yang artinya semakin tinggi kondisi tingkat motivasi belajar siswa maka akan menudukung tingkay hasil belajar.
\end{abstract}

\begin{abstract}
Aim in this study is whether or not there is a relationship between the SocioEconomic Status of Parents with physical education learning achievement and Student Learning Motivation with Physical Education Learning Achievement at SMA Negeri 1 Nganjuk in 2021 and whether or not there is a relationship between parents' socioeconomic status and achievement motivation together. the same as physical education learning achievement at SMA Negeri 1 Nganjuk in 2021. This study uses a correlational approach using a survey method. The results of this study are the results of product moment correlation analysis showing the calculated $r$ value of $0.719<$ rtable (0.05) (111) (0.165) so it can be concluded that there is a positive and influential relationship between socioeconomic and student achievement at SMAN 1 Nganjuk in terms of health education lessons. The results of the product moment correlation analysis show that the calculated $r$ value is $1>$ rtable (0.05)(99) (0.165) indicating there is a positive relationship. So, it can be concluded that there is a relationship between motivation and student learning outcomes of SMAN 1 Nganjuk in physical education subjects. The relationship is unidirectional, which means that the higher the condition of the student's level of motivation, the higher the level of learning outcomes.
\end{abstract}




\section{PENDAHULUAN}

Perubahan yang dialami saat pergeseran dari masyarakat tradisional ke masyarakat modern menimbulkan banyak pergeseran dalam struktur masyarakat dari lembaga awl ke lembaga baru dengan aturan yang cukup berbeda. Pergeseran tersebut mneimbulkan banyak perbedaan terhadap lapisan masyarakat. Sehingga dalam masyarakat memiliki status sosial yang berbeda-beda. Status sosial dan ekonomi orang tua cukup memiliki dampak terhadap cara mengasuh anakl dalam bidang sosial maupun pendidikan.

Pemerintah memfasilitasi para generasi muda dengan adanya pendidikan. Pendidikan yang dimaksud yaitu dalam bentuk sekolah. Sekolah merupakan tempat untuk menuntul ilmu tanpa melihat latar belakang sosial maupun ekonomi para siswanya. Pada umumnya memang anak atau siwa yang berasalah dari ekonomi menengah keatas lebih mendapatkan bimbingan serta arahan dalam bidang pendidikan contohnya les tambahan dan lain sebagianya. Sedangkan untuk anak atau siswa yang berasal dari ekomoni menengah kebawah, mereka cenderung kurang mendapatkan perhatian dari orang tua dalam bidang pendidikan karena mereka lebih memikirkan bagaimana cara memenuhi kebutuhan sehari-harinya.

Salah satu pembentuk moral pada anak yaitu keluarga. Keluarga adalah lembaga sosial pada anak yang dimana semua perbuatan dan perilaku yang dilakukan keluarga akan membentuk karakter pada anak. Karena anak akan mencontoh tingkah laku atau pola perilaku keluarga baik maupun buruk. Oleh karena itu keluarga harus memberikan contoh yang baik pada anak agar anak dapat mencerminkan tingkah laku perbuatan keluarga dalam bidang sosial atau pun bidang lainnya. Selain itu, keluarga bertanggung jawab dalam penyediaan dana dalam bidang pendidikan. Jika orang tua atau keluarga dalam kondisi ekonomi stabil maka akan mempermudah dalam hal menunjang pendidikan anak. Sedangkan jika keadaan ekonomi keliarga dalam kondisi rendah maka akan menghambat dalam bidang pendidikan anak. Contohnya: anak ingin mengikuti bimbingan belajar untuk menunjang kegiatan belajarnya namun dengan harga yang cukup mahal. Jika anak itu inging sekali mengingkuti bimbingan belajar namun orang tua keberatan dengan harga bimbingan belajar tersebut maka pendidikan anak menjadi terhambat. Dengan demikian, keberhasilan suatu pendidikan ditunjang oleh beberapa faktor diantaranya kondisi sosial ekonomi orang tua yang meliputi pendidikan, pekerjaan, tingkat pendapatan dan kepemilikan asset. Oleh karena itu, keadaan sosial ekonomi keluarga yang berbeda-beda menimbulkan motivasi belajar siwa yang berbeda pula.

SMA N 1 Nganjuk adalah salah satu sekolah SMA negeri yang berprestasi di Kabupaten Nganjuk. Sekolah tersebut 
memiliki latar belakang yang beraneka ragam, baik dari kepribadian, proses kegiatan pembelajaran sampai kodisi sosial ekonomi orang tua yang berbeda. Keanekaragamaan kondisi sosial ekonomi orang tua salah satunya dapat dilihat dari barang barang yang dimiliki atau dipakai oleh siswa antara lain: kendaraan yang dipakai saat berangkat sekolah seperti motor, sepeda atau jalan kaki. Kemudian dari sarana dan prasarana pembelajaran yang dimiliki antara lain: alat tulis, handphone dan laptop. Kondisi sosial ekonomi orang tua siswa di SMA N 1 Nganjuk yang beraneka ragam mempengaruhi semangat atau motivasi belajar siswa dalam pembelajaran. Tujuan dari penelitian ini adalah ada tidaknya hubungan antara Kondisi Sosial Ekonomi Orang Tua dengan prestasi belajar pendidikan jasmani serta Motivasi Belajar Siswa Dengan Prestasi Belajar Pendidikan Jasmani Di SMA Negeri 1 Nganjuk Tahun 2021 dan ada tidaknya hubungan status sosial ekonomi orang tua dan motivasi berprestasi secara bersama-sama dengan prestasi belajar Pendidikan Jasmani Di SMA Negeri 1 Nganjuk Tahun 2021.Dari uraian permasalahan maka peneliti mengambil judul "Hubungan Status Sosial Ekonomi Orang Tua Dan Motivasi Belajar Siswa Dengan Prestasi Belajar Pendidikan Jasmani Di SMA Negeri 1 Nganjuk Tahun 2021”.

\section{KAJIAN LITERATUR}

\section{A. Status Sosial Ekonomi Orang Tua}

Status sosial ekonomi orang tua merupakan status yang dimiliki oleh orang tua di dalam keluarga. Status sosial ekonomi orang tua menurut Sunyoto Usman bahwa status sosial ekonomi tercermin pada pemikiran atau penguasaan kekayaan, prestige dan kekuasaan ekonomi. Status sosial merupakan sekumpulan hak dan kewajiban yang dimiliki seseorang dalam masyarakatnya. Disamping itu, menurut Dimyati Mahmud bahwa status sosial ekonomi meliputi tingkat pendidikan orang tua, jenis pekerjaan dan penghasilan orang tua, jabatan orang tua, fasilitas khusus dan barang-barang berharga yang ada di rumah seperti radio, televisi, mesin cuci, almari es, dan sebagainya.

\section{B. Motivasi Belajar Siswa}

Pengertian Motivasi Belajar W.S. Winkel (1983:27) mengemukakan motivasi belajar adalah daya penggerak secara keseluruhan yang berasal dari dalam diri siswa untuk menimbulkan kegiatan belajar, yang menjamin kelangsungan dan memberikan arah pada kegiatan belajar tersebut hingga tujuan yang dikehendaki siswa akan tercapai. Menurut Sugihartono, dkk (2007: 78) motivasi belajar memegang peranan yang sangat penting untuk pencapaian prestasi belajar siswa, karena motivasi belajar yang tinggi akan terlihat dari ketekunan yang tidak mudah menyerah meskipun dihadapkan oleh beberapa kendala.

\section{Sikap Siswa Yang Menunjukkan Motivasi}

Motivasi tinggi tersebut dapat ditemukan dalam sikap siswa, antara lain:

1) Tingginya kualitas keterlibatan siswa dalam belajar. 


\begin{tabular}{|c|c|c|}
\hline Unipa Surabaya & $\begin{array}{c}\text { Journal STAND: Sports and Development } \\
\text { http://jurnal.unipasby.ac.id/index.php/stand/about/submissions } \\
\text { jurnal.stand@unipasby.ac.id }\end{array}$ & $\rightarrow 7$ \\
\hline
\end{tabular}

2) Tingginya keterlibatan afektif siswa dalam belajar.

3) Tingginya upaya siswa untuk menjaga agar senantiasa memiliki motivasi belajar. Berdasarkan pendapat di atas motivasi belajar adalah sebuah dorongan untuk melakukan sesuatu hal yang diwujudkan dalam sebuah tindakan untuk melakukan kegiatan belajar dalam mencapai sebuah tujuan yang diharapkan.

\section{Macam-Macam Motivasi Belajar}

Macam-Macam Motivasi belajar Menurut Sardiman (2006:68), terdapat dua jenis motivasi belajar yaitu:

1) Motivasi Intrinsik Motivasi intrinsik adalah motivasi yang menjadi aktif atau berfungsinya tidak perlu ada perangsang dari luar, karena dalam diri setiap individu sudah ada dorongan untuk melakukan sesuatu. Dengan demikian, tingkah laku yang dilakukan seseorang disebabkan oleh kemauan sendiri bukan dorongan dari luar.

2) Motivasi Ekstrinsik Motivasi ekstrinsik merupakan motif yang aktif dan berfungsi karena adanya dorongan atau rangsangan dari luar.

Tujuan yang diinginkan dari tingkah laku yang digerakkan oleh motivasi ekstrinsik terletak diluar tingkah laku tersebut. Penguatan motivasi-motivasi belajar tersebut berada di tangan para guru sebagai pendidik dan anggota masyarakat yang lain. Guru sebagai pendidik bertugas memperkuat motivasi belajar selama minimum 9 tahun pada usia wajib belajar. Orang tua bertugas memperkuat motivasi belajar sepanjang hayat.

\section{Prestasi belajar Penjasorkes \\ Pengertian Prestasi Belajar}

Prestasi belajar merupakan suatu hasil belajar dengan pencapaian kompetensikompetensi yang telah dilaksanakan siswa. Menurut Nana Syaodih Sukmadinata (2003: 102-103) "prestasi belajar merupakan realisasi atau pemekaran dari kecakapan-kecakapan potensial atau kapasitas yang dimilki seseorang. Penguasaan hasil belajar oleh seseorang dapat dilihat dari perilakunya, baik perilaku dalam bentuk penguasaan pengetahuan, keterampilan berpikir maupun keterampilan motorik." Sedangkan menurut Purwanto (2011: 49) prestasi belajar adalah perwujudan kemampuan akibat perubahan perilaku yang dilakukan oleh usaha pendidikan. Kemampuan menyangkut ranah kognitif, afektif dan psikomotorik. Prestasi belajar merupakan realisasi tercapainya tujuan pendidikan, sehingga hasil belajar yang diukur sangat tergantung kepada tujuan pendidikannya.

\section{Pengertian Pendidikan Jasmani}

Menurut Undang-undang No. 4 tahun 1950 tentang dasardasar pendidikan dan pengajaran pasal 9 bahwa "Pendidikan jasmani yang menuju kepada keselarasan antara tumbuhnya badan dan perkembangan jiwa dan merupakan suatu usaha untuk membuat bangsa Indonesia menjadi bangsa yang sehat dan kuat lahir batin, diberikan pada segala jenis sekolah". 
Pendidikan jasmani menurut Beley dan Field (dalam Suranto, dkk. 2004) mendefinisikan pendidikan jasmani sebagai proses yang menguntungkan dalam penyesuaian dari belajar gerak, neuro-muscular, social, kebudayaan, baik emosional dan etika sebagai akibat yang timbul melalui pilihannya yang baik melalui aktivitas fisik yang menggunakan sebagian besar otot tubuh.

Penelitian yang peneliti teliti menggabungkan ketiga aspek kondisi ekonomi orang tua, motivasi belajar dengan prestasi belajar. Kondisi sosial ekonomi orang tua memberikan kontribusi terhadap sumber belajar siswa. Dengan adanya kondisi sosial ekonomi orang tua yang baik akan memudahkan dalam penyediaan fasilitas belajar bagi siswa. Hal ini juga akan menumbuhkan semangat dan motivasi belajar siswa dalam belajar. Dengan adanya semangat dan motivasi yang besar maka proses pembelajaran akan cepat ditransfer dari guru kepada siswa sehingga mudah untuk menerima materi maupun menjawab soal pembelajaran penjasorkes . Karena adanya kondisi sosial ekonomi orang tua dan motivasi belajar siswa yang bagus maka akan membuat prestasi belajar siswa akan meningkat. Sebaliknya apabila kondisi sosial ekonomi orang tua dan motivasi belajar siswa kurang maka prestasi belajar siswa akan turun.

\section{METODE PENELITIAN}

Penelitian ini menggunakan Pendekatan Korelasional dengan menggunakan metode survey menurut (maksum, 2014 hal. 84) survey adalah penelitian yang mengambil sampel dari satu populasi dan menggunakan kuesioner sebagai alat pengumpul data yang pokok. Populasi dalam penelitian ini adalah siswa SMA Negeri 1 Nganjuk yang mengikuti mata pelajaran penjas dengan jumlah 1041 siswa. Dalam hal ini sampel diambil secara Probability sampling. Sedangkan sampelnya adalah siswa kelas XI IPA5, XIIPA6 dan XIIPA7 SMA Negeri 1 Nganjuk dengan jumlah 115 Penentuan sampel dilakukan dengan cara pengundian dengan sistem simple random sampling karena ini merupakan teknik sampling yang memberikan peluang yang sama bagi individu yang menjadi anggota populasi untuk dipilih menjadi anggota sampel.

Instrument merupakan alat yang digunakan untuk mengumpulkan data yang ingin diamati, Teknik pengumpulan data yang digunakan dalam penelitian ini adalah kuisioner. Kuesinior adalah sekumpulan daftar pertanyaan atau pernyataan tertulis yang diberikan pada subyek penelitian (Arikunto, 2009).

\section{HASIL DAN PEMBAHASAN}

Menurut Hamalik, motivasi berasal dari kata motif yang berarti dorongan yang terarah kepada pemenuhan psikis dari rokhaniah. Sehingga motivasi adalah perubahan energi dalam diri (pribadi) seseorang yang ditandai dengan timbulnya perasaan dan reaksi untuk 


\begin{tabular}{|c|c|}
\hline Unipa Sumabaya & $\begin{array}{c}\text { Journal STAND: Sports and Development } \\
\text { http://jurnal.unipasby.ac.id/index.php/stand/about/submissions } \\
\text { jurnal.stand@unipasby.ac.id }\end{array}$ \\
\hline
\end{tabular}

mencapai tujuan (Susilo, 2013). Motivasi dibedakan menjadi 2 yaitu:

1. Motivasi instrinsik, yaitu motivasi aktif yang muncul dari dalam diri seseorang tanpa ransangan dari luar untuk melakukan sesuatu demi sesusatu itu sendiri (tujuan itu sendiri).

2. Motivasi ekstrinsik, adalah motivasi yang timbul akibat pengaruh dari luar individu, apa karena ajakan, suruhan atau paksaan orang lain sehingga dngan keadaan demikian seseorang mau meakukan sesuatu Dalam hal ini, motivasi belajar sendiri merupakan dorongan yang timbul baik dari dalam maupun luar individu seseorang, sehingga timbul rasa yang mengarah untuk belajar. Motivasi akan belajar ini dapat timbul dalam diri seseorang dengan dipengaruhi banyak faktor. Faktor-faktor pendorong motivasi belajar sangat beragam salahsatunya ialah kondisi ekonomi.

Berdasarkan observasi penghasilan orang tua siswa SMA Negeri 1 Nganjuk, pekerjaan orang tua siswa lebih banyak bekerja sebagai pegawai (swasta/PNS/ABRI/TNI/Polisi). Pegawai memiliki penghasilan tetap, sehingga mereka memenuhi kebutuhan sendiri dengan penghasilan pokok bulanan.

SMAN 1 Nganjuk merupakan salah satu sekolah di kabupaten nganjuk dengan rata-rata kondisi ekonomi orang tuanya merupakan menengah ke atas. Berdasarkan data survey dari 90 siswa baik laki-laki maupun perempuan, diketahui bahwa orang tua siswa memiliki rata-rata penghasilan diatas $\mathrm{Rp}$. 1.300.000.

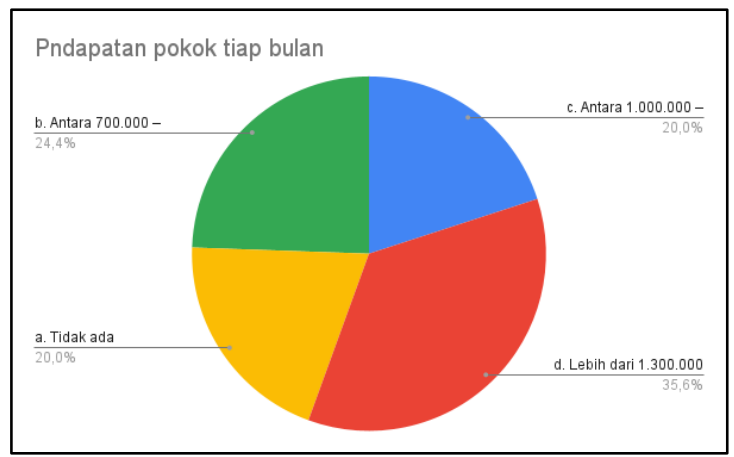

Gambar 1. Presentase Pendapatan

Dari data survey diatas diperoleh 20\% memiliki penghasilan Rp. 0 - 700.000 dengan jumlah siswa sebesar 18 orang, penghasilan antara Rp 700.000 sampai dengan 1.000 .000 sebesar 24,4 \% dengan jumlah 22 orang, penghasilan antara $\mathrm{Rp} \quad 1.000 .000$ sampai dengan 1.300.000 sebesar 20\% dengan jumlah 18 orang, serta penghasilan diatas Rp. 1.300.000 sebesar $35 \%$ dengan jumlah 32 orang. Data tersebut diperoleh dari hasil peresntase jumlah orang tua siswa dengan pekerjaan orang tua siswa dengan sebaran data diatas. Dari data presentase rata-rata kondisi ekonomi siswa SMAN 1 Nganjuk memiliki keadaan ekonomi yang mendukung. Kepemilikan asset sebagai pendukung pembelajaran memadai, sebagaimana data survey berikut:

Volume 2 Nomor 2 Tahun 2021 | 82 


\begin{tabular}{|c|c|}
\hline Unteurnal STAND: Sports and Development \\
unipa Sumabaya
\end{tabular} $\begin{gathered}\text { Journal.unipasby.ac.id/index.php/stand/about/submissions } \\
\text { jurnal.stand@unipasby.ac.id }\end{gathered}$

Tabel 1. Alat komunikasi yang dimiliki keluarga

\begin{tabular}{lcc}
\hline \multicolumn{1}{c}{ Jenis } & Jumlah \\
\hline HP non-internet & 4 \\
HP Smartphone & & 85 \\
Telepon rumah, & HP & \\
Smartphone & & 1 \\
Grand Total & $\mathbf{9 0}$ \\
\hline
\end{tabular}

Dari tabel berikut maka dapat diperoleh presentase data sebagai berikut :

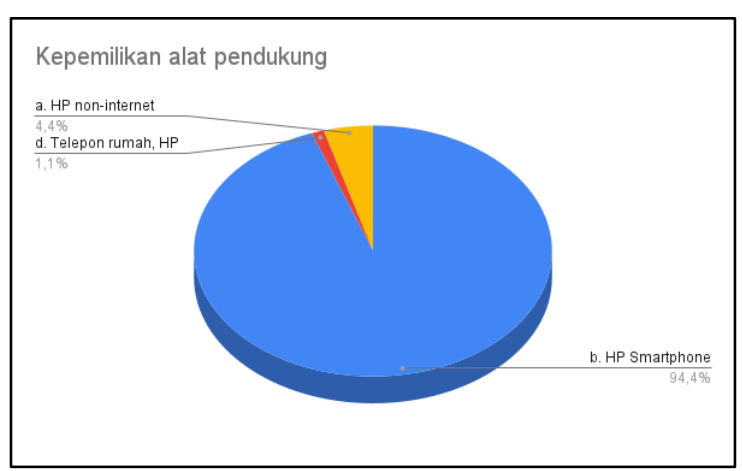

Gambar 2. Alat komunikasi yang dimiliki keluarga

Tabel dan gambar pie chart di atas menjelaskan dari 90 responden sebesar $94,4 \%$ memiliki HP smartphone yang terhubung dengan jaringan internet.

Adapun kecenderungan motivasi belajar siswa terhadap mata pelajaran penjaskes :

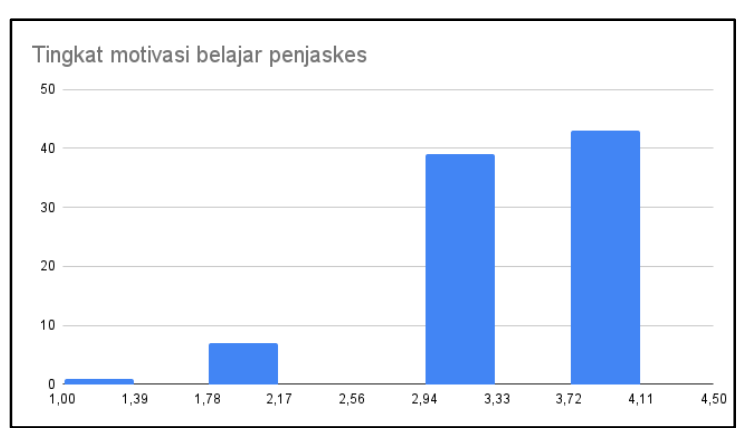

Gambar 3. Motifasi Belajar

Data diatas merupakan skala tingkat motivasi belajar siswa SMAN 1 Nganjuk terhadap mata pelajaran penjaskes, dari data tersebut menunjukkan antusias siswa dalam berpartisipasi dalam kegiatan pembelajran penjaskes sangat tinggi. Lebih dari $60 \%$ siswa dari total 90 orang memilih setuju dan sangat setuju dalam pernyataan "Saya berusaha untuk berhasil dalam mengikuti mata pelajaran penjasorkes yang disampaikan oleh guru"

Dalam survey juga menunjukkan tingkan usaha yang dikeluarkan siswa SMAN 1 Nganjuk cenderung tinggi untuk memperoleh hasil yang tinggi dalam mata pelajran penjaskes.

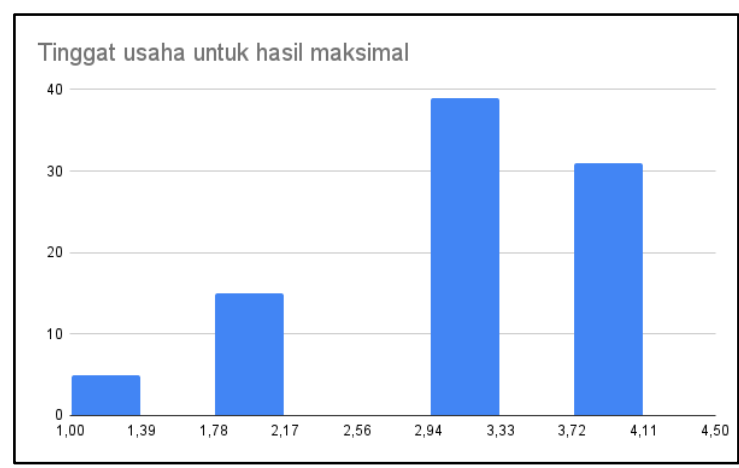

Gambar 4. Tingkat Usaha

Pada data histograf diatas menunjukkan skala yang tinggi usaha yang dilakukan siswa dalam melaksanakan kegiatan pembelajaran penjaskes.

Selanjutnya diambil satu responden dengan kondisi ekonomi terendah dari tiga faktor indikator yaitu pendapatan kepemilikan alat komunikasi, serta gas pangan. Tetapi dari hasil survey menunjukkan dari 12 butur indikator faktor internal terdapat 9 butir dengan skala 4 dan 3 lainnya skala 3 . Lalu diambil 1 responden dengan kondisi ekonomi paling tinggi dengan tiga indikator pendapatan, 
kepemilikan alat komunikasi paling madai, serta gas pangan, memilih 8 dengan skala 4 dari total 12 indikator. Dari adanya data tersebut keterkaitan antara kondisi ekonomi dengan motivasi belajar siswa dapat berhubungan. Namun, kamauan internal juga berbengaruh besar.

\section{Hubungan Sosial Ekonomi dengan Hasil Belajar Siswa Pada Mata Pelajaran Penjaskes}

Hasil dari data survey menunjukkan sebagian besar keadaan ekonomi siswa SMAN 1 Nganjuk baik atau mendukung. Data menunjukkan $35 \%$ orang tua siswa memiliki pendapatan tetap diiringi dengan hasil data survey berupa tingkat motivasi belajar siswa terhadap mata pelajran penjaskes sangan tinggi yaitu di rentang tiga hingga empat, dari nilai tertinggi 4. Hasil analisis korelasi product moment di atas menunjukkan nilai $r$ hitung sebesar $0,719<$ rtabel $(0,05)(111)$ $(0,165)$ maka dapat disimpulkan ada hubungan yang positif dan berpengaruh antara sosial ekonomi dengan prestasi belajar siswa SMAN 1 Nganjuk dalam mata pelajran penjaskes. Hal ini dapat diartikan mempunyai hubungan yang searah yang artinya semakin tinggi kondisi sosial ekonomi keluarga maka akan menudukung tingkay hasil belajar siswa

\section{Hubungan Motivasi Dengan Hasil}

Belajar Siswa Pada Mata Pelajaran Penjaskes

Hasil analisis korelasi product moment di atas menunjukkan nilai $r$ hitung sebesar $1>$ rtabel $(0,05)(99)(0,165)$ menunjukkan ada hubungan yang positif. Maka, dapatdisimpulkan ada hubungan antara motivasi dengan hasil belajar siswa SMAN 1 Nganjuk dalam mata pelajran penjaskes. Hubungan yang searah yang artinya semakin tinggi kondisi tingkat motivasi belajar siswa maka akan menudukung tingkay hasil belajar.

\section{KESIMPULAN}

Hubungan kedua data tersebut dapat dijadikan kesimpulan bahwa keadaan ekonomi yang mendukung menjadi salah satu faktor pendorong motivasi belajar siswa yang antusias dalam pembelajaran penjaskes. Namun, dalam hal tersebut motivasi belajar dari internal juga sangat diperlukan. Karena dorongan intrinsik dalam diri seseorang juga akan meningkatkan motivasi belajar yang baik.

\section{Daftar Pustaka}

Arikunto, S, Suhardjono \& Supardi (2009), Penelitian Tindakan Kelas. Jakarta: Bumi Aksara.

Dimyati, Mahmud. (1990). Psikologi Pendidikan: Suatu Pendekatan terapan, Yogyakarta: BPFE.

Maksum, A. (2014). Metode Penelitian, Surabaya: Unesa expres.

Nana Syaodih S. (2003). Landasan Psikologi Proses Pendidikan. Bandung: PT Remaja Rosdakarya.

Purwanto. (2011). Evaluasi Hasil Belajar. Yogyakarta: PT Pustaka Belajar. 
Sardiman A.M. (2006). Interaksi Dan Motivasi Belajar Mengajar. Jakarta : PT. Raja Grafindo.

Sugihartono, dkk. (2007). Psikologi Pendidikan. Yogyakarta: UNY Press.

Suranto, dkk. (2004). Pengetahuan Umum Pendidikan Jasmani dan Keehatan. Jakarta: Departemen Pendidikan dan Kebudayaan.

Usman Sunyoto. (2004) Pembangunan Dan Pemberdayaan Masyarakat.Yogyakarta : Pustaka Pelajar

Winkel, W.S. (1983). Psikologi Pendidikan dan Evaluasi Belajar. Jakarta: PT. Gramedia 